\title{
Succession Process: A Chance for Rebirth or Failure of a Family Business
}

\author{
Mojca Duh ${ }^{1}$ \\ ${ }^{1}$ Faculty of Economics and Business, University of Maribor, Maribor, Slovenia \\ Correspondence: Mojca Duh, Faculty of Economics and Business, University of Maribor, Razlagova 14, 2000 \\ Maribor, Slovenia. Tel: 386-2-229-0253. E-mail: mojca.duh@uni-mb.si
}

Received: December 19, 2014

Accepted: February 2, 2015

Online Published: February 27, 2015

doi:10.5539/ijbm.v10n3p45

URL: http://dx.doi.org/10.5539/ijbm.v10n3p45

\begin{abstract}
Family business succession has been identified in the majority of research studies as a critical period in a life cycle that often results in failure of a family business. The main purpose of this study is to explore succession as a process of a family business rebirth by enhancing the future leader's innovativeness. Since knowledge is recognized as enabler of innovations, the study focuses on the intersections of innovation, knowledge and family business succession. The model of the successor's innovativeness as precondition for the family business's rebirth is proposed. Two main constructs being of crucial importance for the family business's rebirth emerged from the model. The first one is the process of creation of new knowledge through four knowledge conversion modes and the second one is the "ba" as a shared concept where knowledge is created. We find both constructs as important guidelines for future theoretical and empirical research.
\end{abstract}

Keywords: family business, succession, innovation, innovativeness, knowledge, knowledge creation

\section{Introduction}

This study addresses succession process in family businesses and explores how knowledge transferred and created during succession enhances a successor's innovativeness thereby enabling rebirth of a family business. Family businesses are an important group of enterprises within the small and medium-sized (SME) sector and many studies confirmed the importance of these enterprises for national economies (Astrachan \& Shanker, 2003; IFERA, 2003; Mandl, 2008). It is estimated that $70 \%$ to $80 \%$ of European enterprises are family ones and $40 \%$ to $50 \%$ of all employees work in family businesses (Mandl, 2008). In the United States, family enterprises represent $80 \%$ of business organizations and employ more than $50 \%$ of all employees (McCann, DeMoss, Dascher, \& Barnett, 2003).

Succession in management and ownership has been found in several researches as one of the most challenging processes in family businesses (e.g., Miller, Steier, \& Le Breton-Miller, 2003; Morris, Williams, Allen, \& Avila, 1997; Sharma, Chrisman, \& Chua, 2003). This is especially due to some research results indicating that only $24 \%$ to $30 \%$ of first generation family businesses survive to the second (Kets de Vries, 1993; Miller et al., 2003; Morris et al., 1997) and less than 10\% succeed to the third family generation (Le Breton-Miller, Miller, \& Steier, 2004). Failures in successions represent a serious problem not only for family businesses and their employees, but also for national economies. Even though, family business succession is identified as a critical period in a life cycle, there are also some authors suggesting that succession should be viewed as a strategic opportunity for family businesses coping with rapidly changing environmental conditions (e.g., Cabrera-Suárez, De Saa-Pérez, \& García-Almeida, 2001; Dyck, Mauws, Starke, \& Mischke, 2002). However, we lack explanation on how this can be achieved. Therefore, the main motivation of this study is to broaden our understanding on how succession could contribute to rebirth of a family business during and after the transfer of control to the next family generation. The article focuses on the intersections of innovation, knowledge and family business succession since innovations and ability of enterprises to innovate are found to be an effective answer to rapid market and technological changes (e.g., Nonaka, Toyama, \& Konno, 2000) and knowledge has been recognized as enabler of innovations, innovativeness and creativity of individuals and enterprises (e.g., Delgado-Verde, Martín-de Castro, \& Navas-López, 2011; Nonaka et al., 2000; Nonaka \& von Krogh, 2009). Due to central role played by family business leaders (e.g., Sharma, 2004), especially in family SMEs, the innovativeness of predecessors and successors importantly influence family businesses ability to innovate and is therefore of primary concern in our 
research.

The main purpose of this study is to explore succession as a process of a family business rebirth. The model of a successor's innovativeness as precondition for a family business's rebirth is proposed to provide major research constructs guiding future theoretical and empirical research. The theoretical framework of our research presents the knowledge-based view that is "... powerful tool for understanding the nature and transfer of knowledge within the family business" (Cabrera-Suárez et al., 2001, p.37) and the knowledge creation theory which focuses on the dynamic processes of organizational knowledge creation (Nonaka, 1994; Nonaka, von Krogh, \& Voelpel, 2006; Nonaka and von Krogh, 2009). Additional insights are drawn from extensive research cognitions on innovation, creativity and innovativeness (e.g., Anderson, Potocnik, \& Zhou, 2014) as well as from research studies on family business succession since we do not dispose with the succession theory yet (e.g., Sharma et al., 2003; Sharma, Chrisman, \& Gersick, 2012). We limit our research on succession solutions within the owning family. Transfer of leadership and ownership to a member of a next family generation is preferred by numerous family businesses leaders (e.g., Bjuggren \& Sund, 2001; Le Breton-Miller et al., 2004), even though it is not the only possibility. We limit our research on the transfer of leadership from a predecessor to a successor in family SMEs. Usually this process of leadership transfer is followed (or even takes place at the same time) by the transfer of ownership rights (e.g., Handler, 1994; Sharma et al., 2003; Gersick, Davis, McCollom Hampton, \& Lansberg, 1997), that is not addressed in our research.

We find our study to be of importance for at least three reasons. First, the issue of a successor's innovativeness is of crucial importance for survival and progress of a family business when a next generation takes over the control of a business. This is especially true in competitive environments that are characterized by rapid changes and increasing globalization. Research shows that competitive advantage nowadays can be gained only for a limited period of time (e.g., Ambrosini \& Bowman, 2009). Therefore, enterprises must be able to effectively respond to rapid environmental changes in order to build successive temporary advantages (Duh, 2013). Managers of family businesses need to constantly seek for and seize new business opportunities. In order to do that, creativity and innovativeness are needed. Second, the better key people in enterprises understand the process of creating new and using existent knowledge, the more likely they will encourage innovations (e.g., Duh, 2014; Quintaine, Casselman, Reiche, \& Nylund, 2011) that are crucial determinant of enterprises' development and competitiveness. This is especially important due to some indications that family businesses become less innovative in later life cycle stages (e.g., Laforet, 2012). Third, there is a lack of research that would systematically address the relationship between the enhancement of a successor's innovativeness and a rebirth of a family business. Even though family business succession has been studied intensively since 1990s (e.g., Chirico, 2008; Giambatista, Rowe, \& Riaz, 2005; Sharma, 2004) and innovation has been identified as topic that need scholarly attention in the family business research (e.g., De Masis, Frattini, \& Lichtenthaler, 2013; Sharma et al., 2012), we lack research that would address succession as a process of enhancing successors' innovativeness thereby enabling rebirth instead of failure of family businesses over generations.

\section{Family Business Succession}

Succession is identified as one of the major problems family businesses are dealing with (e.g., Miller et al., 2003; Morris et al., 1997; Sharma et al., 2003). Especially intergenerational succession (i.e., succession within a family) represents a crucial point in the lifecycle of any family business and, as such, has been a primary focus of research (e.g., Giambatista et al., 2005; Sharma, 2004). According to research findings two major reasons exist for choosing a successor among family members. First, nepotism is suggested to be a reason for realizing succession within a family (e.g., Gersick et al., 1997), and second, a family member as a potential successor is especially preferred in those family businesses where family business's specific knowledge is considered highly relevant for gaining competitive advantage (e.g., Bjuggren \& Sound, 2001; Royer, Simons, Boyd, \& Rafferty, 2008).

Research findings indicate that family business succession should be seen rather as a process than an event of transferring ownership and leadership control to a successor (Overview of Family Business, 2009). It should be understood as a multistage process that begins even before a potential successor enters the business (Handler, 1994) and is characterized by growing involvement of a successor in the business (Cabrera-Suárez et al., 2001). Taking the perspective of succession as a process several authors have proposed different models and concepts. Le Breton-Miller et al. (2004) define three groups of activities within their model of family business succession process: setting the ground rules, nurturing and development of successor, and leadership transition which can be done parallel to transfer of capital. According to Longenecker and Schoen (1996) the parent-child succession in the leadership of a family business involves a long-term diachronic process of socialization. It means that family successors are gradually prepared for leadership through a life-time of learning experiences. Handler (1994) 
suggests a need of mutual role adjustment between a predecessor and a successor. The author developed a model, according to which, a predecessor evolves from the role of monarch over delegator to advisor. A successor in turn evolves from helper over manager to leader. This short review of the succession process models indicate that considerable attention in research has been devoted to the process of nurturing, preparing and developing of a successor so that he/she is capable to take over the leadership position. This in accordance with the opinion of several authors (e.g., Cabrera-Suárez et al., 2001; Mazzola, Marchision, \& Astrachan, 2008; Chrisman, Chua, \& Sharma, 1998; Sharma \& Rao, 2000) that realization of effective succession depends considerably on the next generation which has to acquire knowledge about the business as well as leadership capabilities.

The preparation of a competent leader is also seen as an important part of succession planning, which is expected to improve probability of the success of a succession process (e.g., Gersick et al., 1997; Motwani, Levenburg, Schwarz, \& Blankson, 2006; Morris et al., 1997; Sharma et al., 2003) and refers to deliberate and formal process that facilitates the transfer of ownership and leadership control. Within the context of preparing a competent leader several research studies address transfer of knowledge during succession process. Transfer of tacit knowledge from a predecessor to a successor and successor's training have been found to be of crucial importance for creating and protecting knowledge (especially tacit one) thereby securing the continuity of a family business over generations (e.g., Sharma, 2004). Family knowledge on special technologies or commercial know-how that distinguish a family business from its competitors have to be transferred to the next generation (Cabrera-Suárez et al., 2001) since it makes customers believe in a high level of products and services (e.g., Dumas, 1998). Training should enable successor to achieve credibility and legitimacy; in this training process a successor must capture both explicit and tacit knowledge that ensure his or her future performance in the top management tasks (Cabrera-Suárez et al., 2001).

Even though researches discussed provides insights into knowledge transfer and processes of developing a competent successor, we lack comprehensive explanation of how a successor's innovativeness as well as a family business's innovativeness can be enhanced during succession thereby providing basis for rebirth of a family business and its prosperity in the next family generation. Since knowledge has been recognized an important source of innovation, we discuss in continuation both constructs, that are knowledge creation and innovations.

\section{Innovations and Innovativeness as Effective Answers to Changing Environmental Conditions}

Innovations and creativity of enterprises have been recognized to be of crucial importance for enterprises' performance, success and long-term survival (e.g., Anderson et al., 2014; Nonaka et al., 2000). According to Drucker (1985) an innovation is a tool of an entrepreneur by which he/she exploits change as an opportunity. Anderson and co-authors $(2014$, p. 1298) define creativity and innovation as “... the process, outcomes, and products of attempts to develop and introduce new and improved ways of doing things. The creativity stage of this process refers to idea generation, and innovation refers to the subsequent stage of implementing ideas towards better procedures, practices, or products". The authors proposed the integrative definition, since recent research in this field shows that boundaries between creativity and innovation are not clear.

Enhancement of innovations and creativity is of special importance in family businesses since research findings indicate that they are more conservative, put less emphasis on creativity and innovation (e.g., Laforet, 2012) and being risk adverse with local business focus (e.g., Mandl, 2008). Reluctance to take external investors due to the fear of losing control might negatively influence a family firm's competitive position (e.g., Mandl, 2008).

Innovativeness of employees has been recognized as an important and requisite attribute of enterprises if they want to survive and prosper (e.g., Litz \& Kleysen, 2001). Many factors leading to innovations have been identified at the individual level (for references see Anderson et al., 2014; Litz \& Kleysen, 2001): divergent thinking, a propensity for risk-taking, cognitive style, intrinsic motivation, domain relevant skills, creativity skills, political prowess, self-confidence, autonomy and openness, energetic charge, and talent. Team climate, group composition, cohesiveness, development, social constructions, and interpersonal interactions has been recognized as the antecedents to innovation at the group level (for references see Litz \& Kleysen, 2001) whereas organizational culture, structure, strategy and strategic planning, learning and acquisitions of knowledge, social capital, and management style of leaders are found to be among factors that are leading to innovations at the organizational level (e.g., for references see Laforet, 2012).

In our study we focus on knowledge that as is found to be a key component of creativity and innovation (e.g., Anderson et al., 2014; Nonaka et al., 2000; Nonaka \& von Krogh, 2009). According to Delgado-Verde et al. (2011) innovation capability of an enterprise depends on its intellectual resources and knowledge and on the ability of a firm to deploy them. The ability to learn is besides the ability to change found to be among the most 
important capabilities that a firm can possess (Barney, Wright, \& Ketchen, 2001). Therefore, governance and incentive structures should be developed to enable learning and generation of new knowledge (Teece, 2007). We address in the continuation of this article the knowledge-based view that highlights relevance of knowledge as a key organizational factor and the knowledge creation theory that complements the static view of knowledge assets in the knowledge-based view of the firm.

\section{Knowledge Creation}

\subsection{Tacit and Explicit Knowledge}

The knowledge-based view of the firm deals with knowledge as the enterprise's strategically important resource for gaining a competitive advantage (e.g., Cabrera-Suárez et al., 2001; Nonaka et al., 2006). Knowledge has been increasingly seen "... as a factor to explain the idiosyncrasies of firms" (Nonaka \& von Krogh 2009, p. 636) and enabler of innovations (Nonaka et al., 2000; Nonaka \& von Krogh, 2009). Knowledge is the capacity to define situation and act accordingly. It is embodied in an individual, and is therefore history dependent, context sensitive, specific and aimed at problem definition rather than problem depiction and problem solving (Nonaka et al., 2006). Nonaka et al. (2000) especially point to the fact that knowledge is context specific; according to the authors (Nonaka et al., 2000, p. 7) “... information becomes knowledge when it is interpreted by individuals and given a context and anchored in the beliefs and commitments of individuals".

One of the most recognized typology of knowledge is the one which differentiates between explicit and tacit knowledge (e.g., Nonaka, 1994; Nonaka \& von Krogh, 2009; Nonaka et al., 2006). Explicit or codified knowledge has a universal character, supporting the capacity to act across context and is always grounded in tacit knowledge (Nonaka \& von Krogh, 2009). As this type of knowledge is easily transmitted in formal, systematic language, it is transferred easily (Nonaka et al., 2000). On the other hand, tacit knowledge can hardly be expressed or formalized due to its personal quality. It is rooted in actions, procedures, routines, commitment, ideals, values and emotions (Nonaka et al., 2000), and appears and develops through the interactions between an individual and situation thereby becoming context specific (Nonaka, 1994). Knowledge is dynamic, since it is created in social interactions amongst individuals and organizations (Nonaka et al., 2000). These interactions are addressed within the knowledge creation theory and are discussed in next section.

\subsection{Knowledge Conversion Modes and "Ba"}

Organizational knowledge creation theory explains dynamic processes of organizational knowledge creation (Nonaka et al., 2006; Nonaka \& von Krogh, 2009). Knowledge creation is understood as a “... continuous process through which one overcomes the individual boundaries and constrains imposed by information and past learning by acquiring a new context, a new view of the world and new knowledge" (Nonaka et al., 2006). The organizational knowledge creation theory aims to explain how tacit and explicit forms of knowledge interact to create new knowledge (Nonaka \& von Krogh, 2009). Within this theory, tacit and explicit knowledge are conceptually distinguished along a continuum (Nonaka \& von Krogh, 2009), and the concept of "knowledge conversion" explains how these two types of knowledge interact. Four "modes" of knowledge conversion are proposed (Nonaka et al., 2006): socialization, externalization, combination and internalization (see Figure 1). In these processes, tacit and explicit knowledge mutually enhance each other towards increasing the capacity to act (Nonaka \& von Krogh, 2009). While each of these four modes of knowledge conversion can create new knowledge independently, the central idea of organizational knowledge creation concentrates on the dynamic interaction between different modes of knowledge conversion (Nonaka, 1994). Knowledge created through each of the four conversion modes interacts in the spiral of knowledge creation; knowledge created through conversion modes can trigger a new spiral of knowledge, thus expanding horizontally and vertically across firm (Nonaka et al., 2000).

Socialization is the process of creating tacit knowledge through shared experiences (Nonaka, 1994). This process enables us to convert tacit knowledge through interactions between individuals (Nonaka et al., 2006). Combination is the process of creating explicit knowledge from explicit knowledge. It involves the use of social processes to combine explicit knowledge held by individuals (Nonaka, 1994; Nonaka et al., 2006). Externalization and internalization are knowledge conversions that both involve tacit and explicit knowledge. Externalization is the conversion of tacit knowledge explicit concepts, while internalization is the conversion of explicit knowledge into tacit one. This conversion mode bears some similarity to the traditional notion of "learning" (Nonaka, 1994; Nonaka \& von Krogh, 200).

Nonaka et al. (2000, p. 14) define "ba" as "... a shared context in which knowledge is shared, created and utilized". Therefore, generation and regeneration of "ba" is crucial in knowledge creation since it provides the energy, quality and place to perform individual conversions and moving along the knowledge spiral. Nonaka et 
al. (2000) especially point out that "ba" does not necessarily present a physical space; besides physical space, it can also be a virtual space or a mental space. However, especially in socialization and externalization, it is important for participants to share time and space. Understanding of the "ba" concept is of special importance, since the knowledge creation is not only individual's activity; the knowledge is created through interactions among individuals or between individuals and their environments, and therefore, the commitment of individuals to "ba" through action and interaction is important.

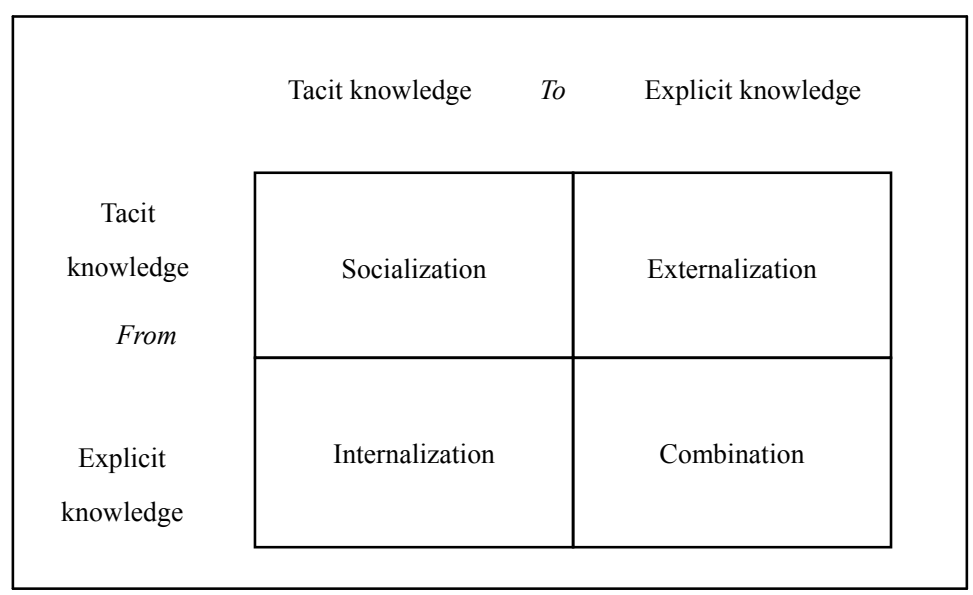

Figure 1. Modes of the knowledge creation (Nonaka, 1994, p.19)

\section{The Model of Enhancing the Successor's Innovativeness for the Family Business's Rebirth}

The proposed model (Figure 2) highlights the main idea of enhancing successor's innovativeness thus creating preconditions for rebirth of a family business. It is based on the concept of knowledge creation as dynamic process that leads to creativity and innovativeness of individuals and enterprises, and on the extensive research cognitions on the family business's succession.

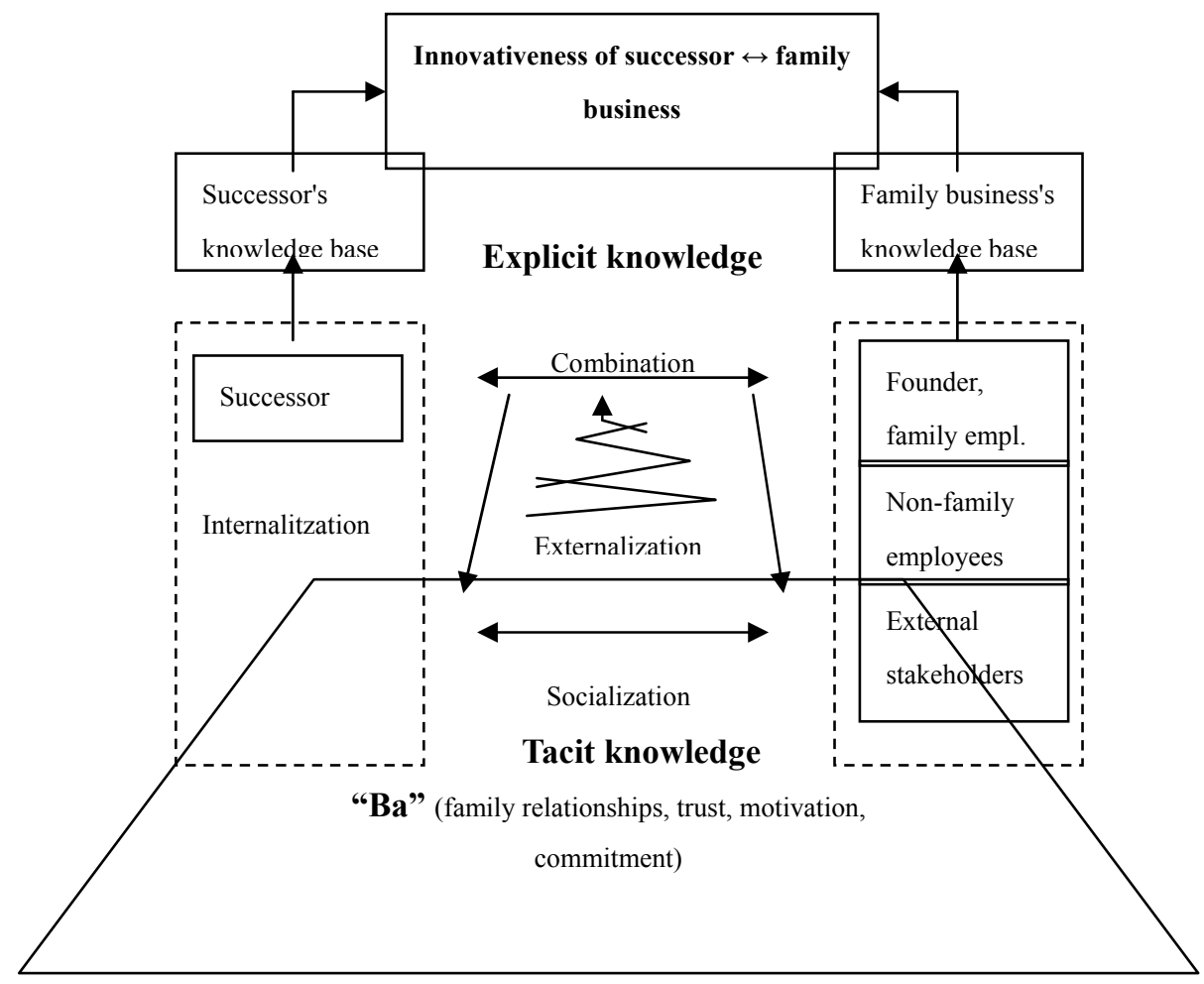

Figure 2. The successor's innovativeness as the precondition for rebirth of a family business 
Two main constructs emerged from the model, and that are: first, the process of creation of new knowledge through four knowledge conversion modes and second, the "ba" as a shared concept where knowledge is created. They are both discussed in the next sections. The main idea for the illustrative presentation of the model presented in the Figure 2 is based on the illustration of the "ba" and knowledge creation designed by Nonaka and Konno (1998). It is adapted in the way that best explains the particularities of a family business and its succession.

\subsection{Knowledge Transfer and Creation during Succession and the Successor's Innovativeness}

The knowledge base of a successor is created during succession through different knowledge conversion modes. Knowledge accumulation should start during growing up of a successor since in that period a successor's impressions of a family business (i.e., a sense of the quality life the family business provides; the business's impact on the parents' marriage and family relationships) is formed and lessons which are learned intentionally or unintentionally during that period will not be easily changed later and will importantly impact the family business's continuity in the future (e.g., Gersick et al., 1997; Motwani et al., 2005). This process of early socialization, where a successor can absorb tacit knowledge about the business at home (Gersick et al., 1997) or by summer and lower category jobs (e.g., Cabrera-Suárez et al., 2001) is especially important for acquiring tacit knowledge of a predecessor (e.g., Duh, 2014). Such experiences prove valuable both in the case of joining the family business immediately after finishing school as well as in the case of joining after obtaining experiences elsewhere. A successor gets familiar with the nature of the business and as a result it is easier for the successor to be accepted, gain credibility, and strengthen important relationships within the business (e.g., Chirico, 2008; Motwani et al., 2006). This can also present the beginning of the creation of the shared vision (e.g., Gersick et al., 1997) of the family business's future which guides the transition from one generation to the next. In the period of growing up also the family culture plays an important role since it stimulates and encourages the successor's innovativeness (Litz \& Kleysen, 2001). Similarly, Zenko and Mulej (2011) ascertain that creative environments in families in the childhood are precondition for creativity and innovation in businesses later on.

The process of transferring a predecessor's tacit knowledge continues with gradual involvement of a successor in a family business and then with his/her full employment. Mentoring and supervising relationships were found as an important informal ways of teaching and learning and as an effective way of transferring critical skills. According to Swap et al. (2001) mentors also teach norms of behavior and transfer knowledge about the values of a firm. Many family business leaders find mentoring as a suitable way of developing tacit knowledge by successors (e.g., Boyd, Upton, \& Wircenski, 1999; Cabrera-Suárez et al., 2001; Chirico, 2008) through socialization and internalization conversion mode. Research carried out by Boyd et al. (1999) showed strong presence of informal mentoring by a family member. Even though this kind of mentoring have numerous strengths (e.g., flexibility, unforced, open communication, caring relationship), the weakness should be considered such as the absence of objectives or an agenda, the presence of emotion (e.g., potential for bias, personality conflicts, unrealistic expectations) and lack of feedback or review. Therefore, it is recommended to incorporate positive aspects of formal mentoring such as “... goal setting and review, recognition of milestone events, and a time line on the relationship" (Boyd et al., 1999, p. 307) being aware of weaknesses such as the forced nature of relationship.

However, the founder's tacit knowledge even though very valuable, is not sufficient for encouraging the successor's creativity and innovativeness. It should be combined with tacit and explicit knowledge that is available within and outside a family business. Valuable knowledge is held by other family and non-family employees, and external stakeholders, such as partners and customers. Therefore, a successor can enlarge his/her knowledge base through interactions with others by actively participating in meetings with business partners (e.g., Mazzola et al., 2008; Nonaka et al., 2006), by involving in accounting practice (e.g., Giovannoni, Maraghini, \& Riccaboni, 2011) and by gradually participating in decision-making (e.g., Kellermanns \& Eddleston, 2004; Motwani et al., 2006) and strategic planning processes (e.g., Mazzola et al., 2008). In these interactions specialized knowledge of family and non-family employees can be acquired as well as tacit knowledge of the family businesses' partners; these processes of socialization, externalization, combination and internalization not only contributes to creation of the successor's knowledge but as well as that of a family business thus enlarging the successor's and the family business's innovativeness. Family meetings (e.g., in the form of a family council) are also recognized as an excellent opportunity for successor's to learn about the rights and responsibilities that come with ownership and management as well as it provides the opportunity for family members to "... articulate their values, needs, and expectations vis-à-vis the company and develop policies that safeguard the long-term interests of the family" (Gersick et al., 1997, p. 237).

Knowledge that is transferred from the outside the family business is also crucial for encouraging the successor's 
innovativeness and for rebirth of a family business. Several authors suggest that not only the formal education is of importance (e.g., Duh, 2014; Morris et al., 1997; Sardeshmukh \& Corbett, 2011) but as well as additional training programs outside the family business since they expose a successor to new ideas and trends (Cabrera-Suárez et al., 2001; Chirico, 2008). This new knowledge should be introduced in a family business in order to offer new perspectives for the family business's rebirth. Valuable experiences and new knowledge are gained by working outside the family business for a certain period of time before taking full responsibility within the family business (e.g., Cabrera-Suárez et al., 2001; Chirico, 2008; Ward, 1987). What is especially important and highlighted in our model is that not only the successor's knowledge base, creativity and innovativeness is enhanced this way but as well as that of a family business. This is in accordance with the main idea of Nonaka (1994) that knowledge creation starts at the individual level moving up to the collective level and then to the organizational level.

We further extend the idea of knowledge transfer and creation during succession as crucial processes for building the successors" innovativeness by applying the idea of "ba". That is especially important in family businesses due to the very emotional nature of the succession process. The "ba" as a critical component of the proposed model is discussed in the next section.

\section{2 "Ba" Context}

Since organizational knowledge creation process during succession has much to do with close interactions between a successor and a predecessor (e.g., Chrisman et al., 1998; Davis \& Tagiuri, 1989), we find of a special importance the concept of "ba" as physical and mental place. Since systemizing "ba", which supports combination, is rather virtual than physical world (Nonaka et al., 2000), our model focuses on the originating "ba" (supporting socialization), dialoguing "ba" (supporting externalization) and exercising "ba" (supporting internalization). Even though several research studies address different enablers of knowledge creation process (e.g., Lee \& Choi, 2003) and impediments for successful knowledge transfer (e.g., Szulanski, 1996), we found in family relationship, trust, motivation and commitment to be of special importance for enhancing successors' innovativeness. They are discussed in continuation.

\subsubsection{Family Relationships}

Research findings (e.g., Nonaka et al., 2006) indicate that high-care relationships favor both transfer and creation of knowledge. Especially in originating "ba", where individuals share tacit knowledge, the relationships between individuals should exhibit a high degree of care for the other (Lee \& Choi, 2003). According to Szulanski (1996) an arduous relationship between the source and the recipient hinders the correct transfer of knowledge. Especially when the knowledge transfer has tacit components and therefore requires numerous individual exchanges, the success of such exchanges depends on the ease of communications and on the "intimacy" of the overall relationship between the source and the recipient. A key feature in a functional relationship must be positive mutual feelings.

Research indicates the importance of the quality of the relationship between a successor and a predecessor in determining the process, timing, and effectiveness of the succession; a good personal relationship between these individuals contributes to the training and development of successors (e.g., Chrisman et al., 1998). The quality of relationships between a predecessor and a successor, specially the smooth and open communication, respect, understanding, and the complementary behavior, is also one of determining factors in effectively transferring knowledge during the succession process (e.g., Cabrera-Suárez et al., 2001; Handler, 1994). Such relationships improve the capacity for mutual learning and friendship and are usually the result of an evolutionary process that begins before the next generation enters the business and continues with the involvement in the work within the business (e.g., Handler, 1994). When there is more than one successor, also the quality of sibling relationship is of importance (e.g., Cabrera-Suárez et al., 2001). Intense kinship ties facilitate face-to-face interactions within the family and the business and help generations to work together before and during the succession process (Chirico, 2008). Such relationships are characteristic of strong and healthy families (Gersick et al., 1997).

So on one hand, family firms can represent a strong social community which is defined as a network of relationships among organizational members leading to open communications and caring relationship (Duh et al., 2010); in this community, personal contacts provide the basis for the exchange of knowledge (e.g., Zahra, Neubaum, \& Larraňeta, 2007). On the other hand, there are some indications of difficulties in family relationships, which escalate during the succession process. Especially, father-son relationships are usually characterized by certain degree of ambivalence and fail to create a suitable environment in which the successor can fully develop his or her potential (e.g., Levinson, 1996; Kets de Vries, 1993; Cabrera-Suárez et al., 2001). The research of Davis and Tagiuri (1989) even indicated that the life cycle stage of the successor (i.e., son) 
relative to that of the preceding generation (i.e., father) affects the quality of the father-son work relationship. Therefore, establishing of "ba" that is characterized by high quality and caring family relationships positively influences the knowledge creation process and the successor's innovativeness thus creating conditions for rebirth of a family business.

\subsubsection{Trust}

Lee and Choi (2003) consider trust as one of the most important enablers of knowledge creation process. According to the authors trust facilitate open and influential knowledge exchange; when relationships among individuals are high in trust, they are more willing to participate in knowledge creation process. Nonaka et al. (2006) expose the importance of mutual trust in relationships among individuals who share tacit knowledge. A relationship characterized by trust between a predecessor and a successor is found to be of great importance for transferring the tacit knowledge during the succession process (Cabrera-Suárez et al., 2001). Family firms are often depicted as being high in trust; the greater the level of trust, the greater the level of openness and opportunities especially for tacit knowledge to be created, shared and transferred over time (Chirico, 2008). However, research (e.g., Lansberg, 1988) also indicates that founders struggling with succession often experience powerful feelings of rivalry and jealously toward successors; the founder might see a successor as a younger rival who waits to take over his place within his "beloved" organization. These feelings become evident as a persistent distrust of the successor's competences and abilities to take over the leadership position. Therefore, we believe that establishing of "ba" characterized by high level of trust between a successor and a predecessor positively influences the knowledge creation process during succession and a successor's innovativeness thus creating conditions for rebirth of a family business

\subsubsection{Motivation and Commitment}

The motivation of a source and a recipient of knowledge are one of important determinant in effective knowledge transfer (e.g., Szulanski, 1996) and together with supervisory encouragement positively influence creativity in work environments (e.g., Anderson et al., 2014). The lack of motivation on the source side can be due to the source's fear of losing a position of privilege and superiority (Szulanski, 1996). In family businesses a predecessor (i.e., a source of knowledge) might suffer motivation problems, feeling that he or she is losing status or importance as succession process develops (Cabrera-Suárez et al., 2001; Lansberg, 1988; Zahra et al., 2007). Therefore, the predecessor's ability to delegate and promote a business environment in which the successor feels free to make both decisions and mistakes are fundamental to the successor's development. In turn, a successor might reject or undervalue the knowledge that a predecessor provides. Some family members may also lack interest in a business or have no desire to learn (e.g., Le Breton-Miller et al., 2004). According to the opinion of some authors not only motivation but also the degree of commitment and interest in a family business that family members have affect the knowledge accumulation process within a family business (Chirico, 2008). Also Nonaka (1994) stressed that individual commitment underlies human knowledge creating activities. Successors' commitment to the business is ranked among the most important attributes of potential successors (Chrisman et al., 1998) and Astrachan et al. (2002) reveal that the family's commitment tends to decrease after the second or third generation. The motivation and commitment of successors are of special importance due to some research results indicating a decreasing willingness of potential successors in founders eyes (i.e., sons and daughters) to take over a family business (e.g., Stavrou, 1999).

The level of commitment and interest in a family business is also influenced by psychological ownership which referred to the family members' possessive emotional feelings and attachment to the family business. A family firm's strong sense of identity and unique social system can foster frequent informal discussions to encourage the transfer of experience and tacit knowledge (Zahra et al., 2007). Therefore, family members concern about sustaining the continuity of the business thorough the creation of knowledge across generations (e.g., Chirico, 2008) can positively impact the implementation of the succession process. Therefore, our model highlights the importance of establishing "ba" that is characterized by the highly motivated and committed successor and predecessor. Such a "ba" positively influences the knowledge creation process and the successor's innovativeness thus creating conditions for the rebirth of the family business.

\section{Conclusions}

The proposed model of the successor's innovativeness suggests that succession can indeed represent an opportunity for the family business rebirth. When succession is understood as the continuous process of the knowledge creation not only at the individual level (i.e., a successor) but as well as at the organizational level through interactions of a successor with other organizational members, new knowledge created enables a family business to successfully address rapid changes in the external environment. The process of creating the 
successor's knowledge base should start early in the childhood and should be followed by different modes of acquiring internally and externally available knowledge through socialization, externalization, combination and internalization. Knowledge creation modes (e.g., mentoring, training, strategic planning etc.) that are incorporated in our model are addressed within the family business research as a useful ways of preparing a successor for the future leadership role. However, the research findings are fragmented and future research should address their integrative impact on the successor's innovativeness.

Our model also highlights the family influence on the "ba" that is an important condition for knowledge creation. Future research should especially consider the impact of family relationships, trust, and motivation and family members' commitment in the integrative manner on the successor's innovativeness. The empirical research should be conducted as qualitative research due to the complexity of the researched phenomenon and novelty of a view on succession as a possible rebirth of a family business by enhancing a successor's innovativeness. Namely, qualitative research is found to be the best way for studying a particular topic "... when the particular topic is new and there is not much previously published research on that topic" (Myers, 2013, p. 9). Especially the case study research has been getting on importance in family business research (e.g., DeMasis \& Kotlar, 2014). We believe that by applying multiple case studies the research cognitions can contribute significantly to the development of the family business succession theory.

\section{References}

Ambrosini, V., \& Bowman, C. (2009). What are dynamic capabilities and are they useful construct in strategic management? International Journal of Management Reviews, 11(1), 29-49. http://dx.doi.org/10.1111/j.1468-2370.2008.00251.x

Anderson, N., Potocnik, K., \& Zhou, J. (2014): Innovation and Creativity in Organizations: A State-of-the-Science Review, Prospective Commentary, and Guiding Framework. Journal of Management, 40(5), 1297-1333. http://dx.doi.org/10.1177/0149206314527128

Astrachan, J. H., Klein, S. B., \& Smyrnios, K. X. (2002). The F-PEC Scale of Family Influence: A Proposal for Solving the Family Business Definition Problem. Family Business Review, 15(1), 45-58. http://dx.doi.org/10.1111/j.1741-6248.2002.00045.x

Barney, J., Wright, M., \& Ketchen, D. J. Jr. (2001). The resource -based view of the firm. Ten years after 1991. Journal of Management, 27(6), 625-641. http://dx.doi.org/10.1177/014920630102700601

Bjuggren, P. O., \& Sund, L. G., (2001). Strategic Decision Making in Intergenerational Successions of Small-and Medium-Sized Family-Owned Businesses. Family Business Review, 14(1), 11-23. http://dx.doi.org/10.1111/j.1741-6248.2001.00011.x

Boyd, J., Upton, N., \& Wircenski, M. (1999). Mentoring in Family Firms: A Reflective Analysis of Senior $\begin{array}{llll}\text { Executives' Perception. Family } & \text { Business }\end{array}$ http://dx.doi.org/10.1111/j.1741-6248.1999.00299.x

Cabrera-Suárez, K., De Saa-Pérez, P., \& García-Almeida, D. (2001). The Succession Process from a Resource and Knowledge-based View of the Family Firm. Family Business Review, 14(1), 37-46. http://dx.doi.org/10.1111/j.1741-6248.2001.00037.x

Chirico, F. (2008). Knowledge Accumulation in Family Firms: Evidence from Four Case Studies. International Small Business Journal, 26(4), 433-462. http://dx.doi.org/10.1177/0266242608091173

Chrisman, J. J., Chua, J. H., \& Sharma, P. (1998). Important Attributes of Successors in Family Businesses: An $\begin{array}{lllll}\text { Exploratory Study. } & \text { Family }\end{array}$ http://dx.doi.org/10.1111/j.1741-6248.1998.00019.x

Davis, J. A., \& Tagiuri, R. (1989). The Influence of Life Stage on Father-Son Work Relationship in Family Companies. Family Business Review, 2(1), 47-74. http://dx.doi.org/10.1111/j.1741-6248.1989.00047.x

Delgado-Verde, M., Martín-de Castro, G., \& Navas-López, J. E. (2011). Organizational knowledge assets and innovation capability: Evidence from Spanish manufacturing firms. Journal of Intellectual Capital, 12(1), 5-19. http://dx.doi.org/10.1108/1469193111109789

De Masis, A., Frattini, F., \& Lichtenthaler, U. (2013). Research on Technological Innovation in Family Firms: Present Debates and Future Directions. Family Business Review, 26(1), 10-31. http://dx.doi.org/10.1177/0894486512466258

De Massis, A., \& Kotlar, A. (2014). The case study method in family business research: Guidelines for 
qualitative scholarship. Journal of Family Business Strategy, 5(1), 15-29. http://dx.doi.org/10.1016/j.jfbs.2014.01.007

Drucker, P. (1985). Innovation and entrepreneurship. New York, NY: Harper \& Row.

Duh, M. (2013). Toward more operational dynamic capabilities concept: possible contribution of the dynamic enterprise construct. International Journal of Business and Management, 8(9), 24-33. http://dx.doi.org/10.5539/ijbm.v8n9p24

Duh, M. (2014). Family Business Succession as Knowledge Creation Process. Kybernetes, 34(5), 699-741. http://dx.doi.org/10.1108/K-08-2013-0172

Duh, M., Belak, J., \& Milfelner, B. (2010). Core Values, Culture and Ethical Climate as Constitutional Elements of Ethical Behavior: Exploring Differences between Family and Non-Family Enterprises. Journal of Business Ethics, 97(3), 473-489. http://dx.doi.org/10.1007/s10551-010-0519-9

Dumas, C. (1998). Women's pathways to participation and leadership in family-owned firms. Family Business Review, 11, 219-228. http://dx.doi.org/10.1111/j.1741-6248.1998.00219.x

Dyck, B., Mauws, M., Starke, F. A., \& Mischke, G. A. (2002). Passing the baton. The importance of sequence, timing, technique and communication in executive succession. Journal of Business Venturing, 17(2), 143-162. http://dx.doi.org/10.1016/S0883-9026(00)00056-2

Gersick, K. E., Davis, J. A., McCollom Hampton, M., \& Lansberg, I., (1997). Generation to Generation. Life Cycles of the Family Business. Boston: Harvard Business School Press.

Giambatista, R. C., Rowe, W. G., \& Riaz, S. (2005). Nothing Succeeds Like Succession: A Critical Review of Leader Succession Literature Since 1994. The Leadership Quarterly, 16(6), 963-991. http://dx.doi.org/10.1016/j.leaqua.2005.09.005

Giovannoni, E., Maraghini, M. P., \& Riccaboni, A. (2011). Transmitting Knowledge across Generations: The Role of Management Accounting Practices. Family Business Review, 24(2), 126-150. http://dx.doi.org/10.1177/0894486511406722

Handler, W. C. (1994). Succession in Family Business: A Review of the Research. Family Business Review, 7(2), 133-157. http://dx.doi.org/10.1111/j.1741-6248.1994.00133.x

IFERA. (2003). Family Business Dominate. Family Business Review, 16(4), 235-239.

Kellermanns, F. W., \& Eddelston, K. A. (2004). Feuding Families: When Conflict Does a Family Firm Good. Entrepreneurship Theory and Practice, 28(3), 209-228. http://dx.doi.org/10.1111/j.1540-6520.2004.00040.x

Kets de Vries, M. (1993). The Dynamics of Family Controlled Firms: The Good and the Bad News. Organizational Dynamics, 21(3), 59-71. http://dx.doi.org/10.1016/0090-2616(93)90071-8

Laforet, S. (2012). Innovation in Small Family Businesses. Chelentham, UK: Edward Elgar. http://dx.doi.org/10.4337/9781781004180

Lansberg, I. S. (1988). The succession conspiracy: Resistance to succession planning in first generation family firms. Family Business Review, 1(2), 119-143. http://dx.doi.org/10.1111/j.1741-6248.1988.00119.x

Le Breton-Miller, I., Miller, D., \& Steier, L. P. (2004). Toward an Integrative Model of Effective FOB

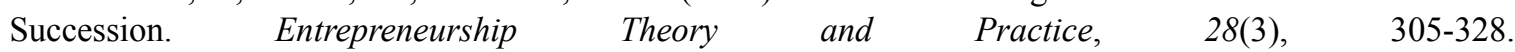
http://dx.doi.org/10.1111/j.1540-6520.2004.00047.x

Lee, H., \& Choi, B. (2003). Knowledge Management Enablers, Processes, and Organizational Performance: An Integrative View and Empirical Examination. Journal of Management Information Systems, 20(1), 179-228.

Levinson, D. (1996). Conflicts That Plague Family Business. (Reprinted from Harvard Business Review, March-April 1971). In C. E. Aronoff, J. H. Astrachan, \& J. L. Ward (Eds.), Family Business Sourcebook II (pp. 378-387). Marietta: Business Owner Resources.

Litz, R., \& Kleysen, R. F. (2001). Your Old Men Shall Dream Dreams, Your Young Men Shall See Visions: Toward a Theory of Family Firm Innovation with Help of the Brubeck Family. Family Business Review, 14(4), 335-352. http://dx.doi.org/10.1111/j.1741-6248.2001.00335.x

Longenecker, J. G., \& Schoen, J. E. (1996). Managment Succession in the Family Business. (Reprinted from Journal of Small Business Management, Vol. 16, No. 3, July 1978), In C. E. Aronoff, J. H. Astrachan, \& J. L. Ward (Eds.), Family Business Sourcebook II (pp. 87-92). Marietta: Business Owner Resources.

Mandl, I. (2008). Overview of Family Business Relevant Issues. Final Report. Austrian Institute for SME 
Research, Vienna. $\quad$ Retrieved July $31, \quad 2009$ from http://ec.europa.eu/enterprise/entrepreneurship/Craft/family_business/family_business_en.htm

Mazzola, P., Marchision, G., \& Astrachan, J. (2008). Strategic Planning in Family Business: A Powerful Developmental Tool for the Next Generation. Family Business Review, 21(3), 239-258. http://dx.doi.org/10.1177/08944865080210030106

McCann, G., DeMoss, M., Dascher, P., \& Barnett, S. (2003). Educational Needs of Family Businesses: Perceptions of University Directors. Family Business Review, 16(4), 283-291.

Miller, D., Steier, L., \& Le Breton-Miller, I. (2003). Lost in time: intergenerational succession, change, and failure in family business. Journal of Business Venturing, 18(4), 513-531. http://dx.doi.org/10.1016/S0883-9026(03)00058-2

Morris, M. H., Williams, R. O., Allen, J. A., \& Avila, R. A. (1997). Correlates of success in family business $\begin{array}{lllll}\text { transitions. Journal of } & \text { Business }\end{array}$ http://dx.doi.org/10.1016/S0883-9026(97)00010-4

Motwani, J., Levenburg, N. M., Schwarz, T. V., \& Blankson C. (2006). Succession Planning in SMEs: An Empirical Analysis. International Small Business Journal, 24(5), 471-495. http://dx.doi.org/10.1177/0266242606067270

Myers, M. D. (2013). Qualitative Research in Business \& Management (2nd ed.). Thousand Oaks, CA: SAGE.

Nonaka, I. (1994). A Dynamic Theory of Organizational Knowledge Creation. Organization Science, 5(1), 14-37. http://dx.doi.org/10.1287/orsc.5.1.14

Nonaka, I., \& Konno, N. (1998). The Concept of "Ba": Building a Foundation for Knowledge Creation. California Management Review, 40(3), 40-54. http://dx.doi.org/10.2307/41165942

Nonaka, I., Toyama, R., \& Konno, N. (2000). SECI, Ba and Leadership: a Unified Model of Dynamic Knowledge Creation. Long Range Planning, 33(1), 5-34. http://dx.doi.org/10.1016/S0024-6301(99)00115-6

Nonaka, I., Von Krogh, G., \& Voelpel, S. (2006). Organizational Knowledge Creating Theory: Evolutionary Paths and Future Advances. Organization Studies, 27(8), 1179-1208. http://dx.doi.org/10.1177/0170840606066312

Nonaka, I., \& Von Krogh, G. (2009). Tacit Knowledge and Knowledge Conversion: Controversy and Advancement in Organizational Knowledge Creation Theory. Organization Science, 20(3), 635-652. http://dx.doi.org/10.1287/orsc.1080.0412

Overview of Family Business. (2009). Overview of Family-Business-Relevant Issues: Research, Networks, Policy Measures and Existing Studies. Final Report of the Expert Group. Retrieved from $\mathrm{http} / /$ ec.europa.eu/enterprise/policies/sme/promoting-entrepreneurship/family-business/\#h2-conclusions.

Quintaine, E., Casselman, R. M., Reiche, S., \& Nylund, P. A. (2011). Innovation as a knowledge based outcome. Journal of Knowledge Management, 15(6), 928-947. http://dx.doi.org/10.1108/13673271111179299

Royer, S., Simons, R., Boyd, B., \& Rafferty, A. (2008). Promoting Family: A Contingency Model of Family $\begin{array}{llll}\text { Business Succession. Family } & \text { Business }\end{array}$ http://dx.doi.org/10.1111/j.1741-6248.2007.00108.x

Sardeshmukh, S. R., \& Corbett, A. C. (2011). The Duality of Internal and External Development of Successors: Opportunity Recognition in Family Firms. Family Business Review, 24(2), 111-125. http://dx.doi.org/10.1177/0894486510391783

Schulze, A., \& Hoegl, M. (2008). Organizational knowledge creation and the generation of new product ideas: A behavioral approach. Research Policy, 37(10), 1742-1750. http://dx.doi.org/10.1016/j.respol.2008.07.002

Sharma, P. (2004). An Overview of the Field of Family Business Studies: Current Status and Directions for the Future. Family Business Review, 17(1), 1-36. http://dx.doi.org/10.1111/j.1741-6248.2000.00313.x

Sharma, P., \& Rao, A.S. (2000). Successor Attributes and Canadian Family Firms: A Comparative Study. Family Business Review, 13(4), 313-322. http://dx.doi.org/10.1111/j.1741-6248.2000.00313.x

Sharma, P., Chrisman, J. J., \& Chua, J. H. (2003). Succession Planning as Planned Behavior: Some Empirical Results. Family Business Review, 16(1), 1-14. http://dx.doi.org/10.1111/j.1741-6248.2003.00001.x 
Sharma, P., Chrisman, J. J., \& Gersick, K. E. (2012). 25 Years of Family Business Review: Reflections on the Past and Perspectives for the Future. Family Business Review, 25(1), 5-15. http://dx.doi.org/10.1177/0894486512437626

Stavrou, E. T. (1999). Succession in Family Businesses: Exploring the Effects of Demographic Factors on Offspring Intentions to Join and Take Over the Business. Journal of Small Business Management, 37(3), 43-61.

Swap, W., Leonard, D., Shields, M., \& Abrams, L. (2001). Using Mentoring and Storytelling to Transfer Knowledge in the Workplace. Journal of Management Information Systems, 18(1), 95-114.

Szulanski, G. (1996). Exploring internal stickiness. Impediments to the transfer of best practice within the firm. Strategic Management Journal, 17(Special Winter Issue), 27-43.

Teece, D. J. (2007). Explicating dynamic capabilities: the nature and microfundations of (sustainable) enterprise performance. Strategic Management Journal, 28(13), 319-1350. http://dx.doi.org/10.1002/smj.640

Ward, J. L. (1987). Keeping the Family Business Healthy. San Francisco: Jossey-Bass Inc. Publishers.

Zahra, S. A., Neubaum, D. O., \& Larraňeta, B. (2007). Knowledge sharing and technological capabilities: The moderating role of family involvement. Journal of Business Research, 60(10), 1070-1079. http://dx.doi.org/10.1016/j.jbusres.2006.12.014

Zenko, Z., \& Mulej, M. (2011). Diffusion of innovative behavior with social responsibility. Kybernetes, 40(9), 1258-1272. http://dx.doi.org/10.1108/03684921111169378

\section{Copyrights}

Copyright for this article is retained by the author(s), with first publication rights granted to the journal.

This is an open-access article distributed under the terms and conditions of the Creative Commons Attribution license (http://creativecommons.org/licenses/by/3.0/). 